\author{
ЦИФРОВІ ІНСТРУМЕНТИ МАРКЕТИНГОВИХ КОМУНІКАЦІЙ \\ ТОРГОВЕЛЬНИХ МЕРЕЖ
}

TRADE NETWORKS' DIGITAL TOOLS OF MARKETING COMMUNICATIONS

УДК 659.182/.187

https://doi.org/10.32843/bses.55-10

\section{Алданькова Г.В.}

к.е.н., доцент касредри

журналістики та реклами

Київський національний

торговельно-економічний університет

Коноплянникова М.А.

к.е.н., доцент кафедри маркетингу

Київський національний

торговельно-економічний університет

\author{
Aldankova Halyna \\ Kyiv National University \\ of Trade and Economics \\ Konoplyannikova Marianna \\ Kyiv National University \\ of Trade and Economics
}

\begin{abstract}
У статті розглянуто цифррові інструменти комунікаційного міксу торговельних мереж. Піәкреслено, що особливості комунікаційної діяльності мережевих підприємств з продажу побутових електротоварів, інфрормаційного та комунікаційного обладнання значною мірою визначаються тенденціями, що склалися на українському ринку рекламних та комунікаційних послуг загалом. Поширення сучасних інфоормаційно-комунікаційних технологій і скорочення споживчого попиту на побутову техніку та електронікувсукупностіспричинилизмінивструктурікомплексумаркетинговихкомунікаційторговельних мереж на користь електронних засобів комунікації замість традиційних. Наведено результати моніторингу, що здійснювався авторами задля виявлення найбільш популярних інструментів просування у покупців побутових електротехнічних товарів, комп'ютерної техніки та засобів зв'язку. Обгрунтовано найбільш дієві цисррові комунікації для різних за віком та статтю споживачів.

Ключові слова: маркетингові комунікації, цифровий маркетинг, торговельна мережа, бренд-комунікації, реклама.
\end{abstract}

Встатьерассмотреныцифрровые инструменты коммуникационного микса торго- вых сетей. Подчеркнуто, что особенности коммуникационной деятельности сетевых предприятий по продаже бытовых электротоваров, информационного и коммуникационного оборудования в значительной степени определяются тенденциями, сложившимися на украинском рынке рекламных и коммуникационных услуг в челом. Распространение современных информационно-коммуникационных технологий и сокращение потреби тельского спроса на бытовую технику и электронику в совокупности обусловили изменения в структуре комплекса маркетинговых коммуникаций торговых сетей в пользу электронных средств коммуникации вместо традиционных. Приведены результаты мониторинга, который осуществлялся авторами с целью выявления наиболее популярных инструментов продвижения у покупателей электротехнических товаров, компьютерной техни ки и средств связи. Обоснованы наиболее действенные цифровые коммуникации для различных по возрасту и полу потребителей.

Ключевые слова: маркетинговые коммуникации, чифрровой маркетинг, торговая сеть, бренд-коммуникации, реклама.

The article discusses digital communication mix tools of retail chains operating in the household appliances and electronics markets in Ukraine. It is emphasized that the peculiarities of the communication activities of trade enterprises selling household electrical goods, information and communication equipment are largely determined by the trends generally prevailing in the Ukrainian market of advertising and communication services. The spread of modern information and communication technologies, devices, and the reduction in consumer household appliances and electronics demand, in aggregate, have caused changes in the structure of the marketing communications complex of retail chains in favor of electronic means of communication instead of traditional ones. The article examines three strategic models of brand communications of the leading retail chains in Ukraine, the content of appeals to consumers. The results of monitoring, carried out to identify the most popular promotional tools for equipment buyers, are presented. A rating of the types of activities on the Internet of users of personal computers and mobile communications has been created. The five most popular types of activities personal computer users on the Internet are engaged in are information search through search engines; viewing social networks; watching videos online; file sharing, downloading music, movies, and emailing. The five most popular types of activities for users of mobile devices include voice communication through mobile operators; sending/receiving SMS; use photo and video cameras; using mobile applications, browsing social networks, and searching for information through search networks. It was revealed that the age audience of the Internet and mobile communications maximally coincides with the audience of the most active buyers of household electrical goods, information, and communication equipment. These are age groups 20-29 and 30-39 years old. On the basis of the study, the most effective digital communications for consumers of household electrical appliances, computer equipment, and communication facilities of different age and sex are substantiated.

Key words: marketing communications, digital marketing, trade network, brand communications, advertising.

Постановка проблеми. Глобальний розвиток інноваційнихтехнологій, фінансово-економічнакриза, пандеміязумовлюютьнадзвичайнудинамічність і непередбачуваність українського ринку побутових електротоварів, інфрормаційного та комунікаційного обладнання. Більшостіторговельнихмереж, щопрацюють на цьому ринку, довелося стикнутися з помітнимскороченнямдоходуйнестабільністюприбутків. Це визначає необхідність пошуку ними есективних засобів залучення та утримання покупців, серед яких одними з найбільш дієвих є маркетингові комунікації.
Аналіз останніх досліджень і публікацій. Теоретичні та методичні основи традиційних засобів просування розглянуто у працях багатьох науковців та фрахівців-практиків. Проте умови здійснення маркетингових комунікацій протягом останнього десятиліття суттєво змінилися, насамперед під впливом стрімкого розвитку новітніх інфрормаційнокомунікаційних технологій. Питання розвитку цифррових засобів комунікаційного міксу розглядали С.А. Назаренко, Н.П. Скригун, К.Ю. Семененко, Л.В. Капінус [1], С.С. Окороков [2]; застосування 
інноваційних технологій просування у галузі торгівлі вивчали Н.В. Лужнова, В.Н. Марченко [3]; засоби digital-маркетингу на ринку IT-техніки досліджували О.М. Азарян, О.В. Кужилєва, І.А. Луговська, М.М. Матвієнко, Л.А. Радкевич [4]; моделі бренд-комунікацій мереж магазинів електроніки аналізувала О.І. Лабурцева [5]. Проте праць, у яких би було окреслено найбільш важливі засоби digital-комунікацій для покупців побутових технічних товарів з торговельною мережею, ще недостатньо. Це визначає актуальність подальших досліджень у цьому напрямі.

Постановка завдання. Недостатнє опрацювання зазначеної тематики визначило мету статті, що полягає у розгляді засобів просування торговельних мереж на ринку побутових електротехнічних товарів, електроніки та засобів зв'язку, обґрунтуванні рекомендацій щодо вибору найбільш актуальних для споживачів digital-інструментів маркетингових комунікацій.

Виклад основного матеріалу дослідження. Особливості комунікаційної діяльності торговельних мереж з продажу побутових електротоварів, інфрормаційного та комунікаційного обладнання значною мірою визначаються тенденціями, що склалися на українському ринку рекламних та комунікаційних послуг загалом.

Динаміка бюджетів основних медіаканалів, за оцінками експертів Всеукраїнської рекламної коаліції, показує, що після 2009 р. більшість каналів демонструє зростання. Безперечним лідером серед медіаканалів є телевізійна реклама; позитивною $є$ також динаміка TV-спонсорства. Приблизно стабільними залишаються бюджети зовнішньої та радіореклами, реклами в кінотеатрах. Єдиний канал, який втрачає позиції, - це реклама в пресі, місце якої впевнено посідає просування у гіперінорормаційному комп'ютерному середовищі. Інтернет-реклама демонструє найвищі темпи зростання (у 52,3 рази за 10 років). Серед немедійніої частини рекламно-комунікаційного ринку України з 2010 р. набирає популярність Loyalty Marketing (розсилання листів, управління базами даних, діяльність контакт-центрів) [6].

O.І. Лабурцева у групі мереж магазинів електроніки ідентифікує три стратегічні моделі брендкомунікацій. Перша група («Ельдорадо», «Фокстрот») - це мережі, що найдовше працюють на ринку, дотримуються «традиційної» комунікаційної стратегії, орієнтуючись на аудиторію середнього віку. Вони інтенсивно використовують телебачення, значно менше зовнішню рекламу, інтенсивність рекламного просування в соціальних мережах та в Інтернеті $€$ середньою. Друга група («Алло», "Comfy", "МOYO”) використовує телерекламу на середньому рівні; водночас у соціальних мережах демонструє помітно вищу активність, ніж попередня група. Активністю реклами в Інтернеті вирізняється лише «Алло». Комунікаційна брендстратегія торговельної мережі «Цитрус» докорінно інша: відмова від реклами на телебаченні, проте лідерство за рекламою в Інтернет, зокрема за відеорекламою, що свідчить про орієнтацію на молодіжну аудиторію. «Цитрус» також має найбільше сторінок у різних соціальних мережах, хоча їхня активність середня [5].

Звісно, під впливом сучасних інорормаційнокомунікаційних технологій та відповідних змін у вподобаннях споживачів протягом останніх років знижується активність «традиційних» комунікацій на користь цисррових. Для успішного розвитку торговельні мережі будуть намагатися застосовувати інструменти цифрового маркетингу, у складі яких вже $є$ або можуть бути веб-сайт, інтернет-реклама, контент-маркетинг, пошуковий маркетинг (включаючи оптимізацію пошукових систем, маркетинг пошукових систем), електронний маркетинг, маркетинг соціальних медіа (SMM), вірусний маркетинг, відеомаркетинг, голосовий пошук, інтернетреклама, мобільний маркетинг тощо. У цифровому маркетингу не існує стандартної покрокової стратегії та конкретного набору інструментів, які би працювали однаково добре для будь-якого підприємства або аудиторії. Перш ніж здійснювати просування, необхідно визначити цільову аудиторію, проаналізувати важливість для неї каналів та інструментів комунікації.

В рамках нашого дослідження вивчалося використання сучасних інфрормаційно-комунікаційних технологій покупцями побутових електротоварів, інфрормаційного та комунікаційного обладнання задля обґрунтування найбільш важливих та дієвих маркетингових комунікацій для різних категорій споживачів.

Однією з найбільш важливих соціодемографрічних ознак, за якою можливо й доцільно сегментувати для відповідної диференціації комунікації, $€$ вік покупців. В табл. 1. подано результати оцінювання представниками вікових груп відносної важливості для них різних інструментів комунікації, що допомагає зробити вибір інструментів, найбільш бажаних для кожної групи.

З урахуванням тенденцій, що склалися на українському ринку медіа, цільову орієнтацію маркетингових комунікацій на ті чи інші сегменти споживачів найзручніше здійснювати за базами даних, які фрормують практично всі торговельні мережі, 3 використанням інструментів цифрових комунікацій, тобто мережі Інтернет через персональні комп'ютери та мобільний зв'язок [1; 3; 4; 5].

Зміст звернень до споживачів може бути різним: статті, інфогррафріка, фротографрії, відео можуть поширюватися через різні засоби мережі Інтернет, такі як веб-сайт, сторінки в соціальних мережах, електронна пошта, відеоканали на "YouTube", a також через різні технічні пристрої. 
Найбільш важливі інструменти маркетингові комунікації для різних вікових груп споживачів побутових електротоварів, інфрормаційного та комунікаційного обладнання

\begin{tabular}{|c|c|}
\hline Вікова група & Інструменти маркетингової комунікації \\
\hline 50 років і старше & $\begin{array}{l}\text { Спонсорство, реклама на телебаченні, реклама в друкованих 3MI, сайт торговельної мережі, } \\
\text { технічний опис в онлайн-каталозі мережі. }\end{array}$ \\
\hline 40-49 років & $\begin{array}{l}\text { Поради друзів, знайомих, належність магазину до конкретної мережі, знижки постійним покуп- } \\
\text { цям, знижка за комплект, подарунок у комплекті, розпродаж, розіграш призів, подарунки, } \\
\text { реклама в друкованих ЗМІ (журнали, газети), реклама в (на) транспорті, відгуки про мережу, } \\
\text { включаючи інформаційно-споживчі портали, реклама електронною поштою. }\end{array}$ \\
\hline 30-39 років & $\begin{array}{l}\text { Сайт торговельної мережі, технічний опис в онлайн-каталозі мережі, реклама в соціальних } \\
\text { мережах, термін існування мережі, спонсорство, "Тrade in" (старе на нове } 3 \text { доплатою), роз- } \\
\text { продаж, подарунки, зовнішнє офрормлення місця продажів (фасад будівлі, вітрина, вивіска), } \\
\text { внутрішня реклама на місці продажу (в торговельній залі). }\end{array}$ \\
\hline 20-29 років & $\begin{array}{l}\text { Соціально-етичний імідж мережі (турбота про співробітників, покупців, зовнішнє середовище, } \\
\text { суспільство), популярність, престижність магазину, позитивний досвід попередньої покупки, } \\
\text { належність магазину до конкретної мережі, спонсорство, знижка за комплект, розстрочка, } \\
\text { реклама на радіо, зовнішня реклама, реклама в поштову скриньку (регулярна публікація това- } \\
\text { рів і цін у друкованих матеріалах магазину), розважальні, навчальні програми в торговельних } \\
\text { залах, сайт торговельної мережі, технічний опис в онлайн-каталозі мережі, реклама в соціаль- } \\
\text { них мережах, реклама в Інтернеті (банерна, контекстна, огляди на інтернет-ресурсах). }\end{array}$ \\
\hline $\begin{array}{l}19 \text { років } \\
\text { і молодше }\end{array}$ & $\begin{array}{l}\text { Мобільні технології (MMS, SMS, мобільні аплікації, QR-код), знижки за акціями, реклама на } \\
\text { телебаченні. }\end{array}$ \\
\hline
\end{tabular}

Джерело: розроблено авторами за результатами власного дослідження

В табл. 2 подано інформацію щодо часток різних вікових груп респондентів серед тих, хто користується Інтернетом через стаціонарні та переносні комп'ютери (ноутбуки, комп'ютерні планшети).

Найбільш активними користувачами Інтернету через персональні комп'ютери є споживачі віком до 40 років, особливо 20-29 років. Якщо пошукові системи, соціальні мережі, електронне листування та перегляд даних про товари на сайтах підприємств актуальні для всіх вікових категорій, то прослуховування музики онлайн, онлайн-ігри, участь у форумах, ведення блогів - це сорера інтересів молоді, а обміном текстовими повідомленнями (наприклад, ICQ) та переглядом програм телебачення, які вже пройшли свій пік популярності, більше цікавляться споживачі середнього віку. Це необхідно враховувати під час орієнтації маркетингових комунікацій на ту чи іншу вікову групу.

На рис. 1 подано рейтинг видів діяльностів мережі Інтернет користувачів персональних комп'ютерів (з розподілом на чоловічу та жіночу аудиторії), складений за результатами нашого дослідження.

У п'ятірку найбільш популярних видів діяльності користувачів персональних комп'ютерів в мережі Інтернет увійшли пошук інформації через пошукові системи (98,00\% респондентів); перегляд соціальних мереж (89,75\%); перегляд відео онлайн (81,75\%); обмін фрайлами, завантаження музики та фрільмів (77,50\%); електронне листування (77,50\%). Також відносно популярні IP-телесронія (“Skype", “Viber", "WhatsApp” тощо; 71,5\%) та перегляд даних про товари й послуги на сайтах підприємств (69,50\%). Надалі популярність помітно скорочується. Отже, доцільно рекомен- дувати торговельним мережам найбільш активно використовувати контекстну рекламу та SEOоптимізацію сайтів, рекламу в соціальних мережах ("Facebook", "Instagram" тощо); створення вірусних відео, які поширюватимуться через платформу "YouTube"; розсилання повідомлень електронною поштою, а також повідомлень у "WhatsApp", "Viber" тощо тим споживачам, які внесені до баз даних. Поза сумнівом, надзвичайно важливу роль відіграють зручні та забезпечені актуальною інформацією сайти мереж.

Розподіл даних за статтю респондентів показав, що чоловіки більш активні в таких видах діяльності, як участь у фрорумах (чоловіки становлять $69,51 \%$ серед усіх, хто надав відповідь); перегляд програм телебачення (64,75\%); онлайнігри (59,84\%); відвідування інсрормаційно-споживчих порталів (58,16\%); перегляд даних про товари й послуги на сайтах підприємств (55,76\%); прослуховування музики онлайн (53,77\%) (рис. 2$)$.

Крім того, під час читання онлайн інформаційних ресурсів чоловіки з великим відривом лідирують серед читачів спеціальних електронних журналів 3 комп'ютерної техніки (щодо ділових та суспільно-політичних видань, то їх однаковою мірою переглядають і чоловіки, і жінки).

Жінки більш активні в обміні текстовими повідомленнями $(60,12 \%)$, веденні блогів $(57,89 \%)$, обміні фрайлами, завантаженні музики та фрільмів (55,16\%), перегляді відео онлайн (55,05\%), IP-телефонії (54,20\%) та електронному листуванні (53,31\%). Щодо перегляду соціальних мереж та читання онлайн інформаційних ресурсів, то частки чоловіків і жінок тут приблизно однакові (рис. 3). 
Частки вікових груп респондентів серед тих, хто користується мережею Інтернет через персональні комп'ютери, \%

\begin{tabular}{|c|c|c|c|c|c|}
\hline \multirow{2}{*}{ Можливості Інтернету } & \multicolumn{5}{|c|}{ Вікові групи, років } \\
\hline & 19 і менше & $20-29$ & $30-39$ & $40-49$ & $50-55$ \\
\hline Пошук інфрормації через пошукові системи & & 25,00 & & & \\
\hline Перегляд соціальних мереж & & 30,64 & & & \\
\hline Перегляд відео онлайн & & 35,78 & & & \\
\hline Обмін фрайлами, завантаження музики й фрільмів & & 25,81 & & & \\
\hline Електронне листування & 24,17 & & & & \\
\hline IP-телесронія & & 36,36 & & & \\
\hline $\begin{array}{l}\text { Перегляд даних про товари й послуги на сайтах } \\
\text { підприємств }\end{array}$ & & 31,29 & & & \\
\hline Прослуховування музики онлайн & & 29,25 & & & \\
\hline Читання онлайн інформаційних ресурсів & & 34,36 & & & \\
\hline Обмін текстовими повідомленнями & & & 31,90 & & \\
\hline Перегляд програм телебачення & & & 30,94 & & \\
\hline Відвідування інформаційно-споживчих порталів & & & 36,07 & & \\
\hline Онлайн-ігри & & 36,73 & & & \\
\hline Участь у форомах & & 30,49 & & & \\
\hline Ведення блогів & $45,6 \%$ & & & & \\
\hline
\end{tabular}

Примітки: відсотки зазначені для тієї вікової категорії, частка якої серед користувачів є найбільшою

Інтенсивність використання можливості: - висока; - середня; - низька.

Джерело: складено авторами за результатами власного дослідження

Отже, можна зробити висновок, що чоловіки в мережі Інтернет віддають перевагу професійним інтересам (форуми, онлайн-журнали) та розвагам, а жінки - спілкуванню; виявлені закономірності можуть бути враховані за необхідності орієнтувати комунікації більшою мірою на чоловічу або жіночу аудиторії.

Розвивається ІТ-галузь, пропонуючи нові можливості для мобільної реклами, яка стає оптимальним інструментом для комунікації 3 аудиторією, а саме 3 користувачами мобільних телефонів, що активно реагують на якісні рекламні пропозиції, пересилають їх знайомим, «діляться» посиланнями в соціальних медіа, в результаті чого інформація про технічні новинки або зниження цін поширюється миттєво. В табл. 3 подано інфрормацію щодо часток різних вікових груп респондентів серед тих, хто здійснює ті чи інші види діяльності в Інтернеті за допомогою мобільних пристроїв.

Найбільш активними користувачами мобільних пристроїв $є$ споживачі віком до 40 років, особливо 20-29 років. Такі інструменти, як голосовий зв'язок (наприклад, телефонні дзвінки клієнтам, що внесені в базу даних), розсилання SMS, контекстна реклама та SEO-оптимізація сайтів, забезпечують вихід практично на всі вікові аудиторії. Щодо завантаження та експлуатації мобільних додатків, відвідування соціальних мереж 3 мобільного пристрою, то це сорера інтересів більш молодого покоління. Відправлення/отримання MMS, пере- гляд відео та програм телебачення більш типові для представників середнього віку. Вихід на аудиторію старше 50 років через використання мобільних пристроїв взагалі видається недоцільним. Ці закономірності необхідно враховувати під час орієнтації маркетингових комунікацій на ту чи іншу вікову групу.

На рис. 4 подано рейтинг видів діяльності користувачів мобільних пристроїв (з розподілом на чоловічу та жіночу аудиторії), складений за результатами нашого дослідження.

У п'ятірку найбільш популярних видів діяльності користувачів мобільних пристроїв увійшли голосовий зв'язок через мобільних операторів (100,00\% респондентів); відправлення/отримання SMS (98,0\%); використання фрото- і відеокамер (98,0\%); використання мобільних додатків $(87,25 \%)$, перегляд соціальних мереж та пошук інфрормації через пошукові мережі (по 67,50\%). Також відносно популярні перегляд відео (60,75\%), відправлення/ отримання MMS $(57,25 \%)$ та прослуховування музики через тр3-плеєр (53,25\%). Решту видів діяльності використовують менше 50\% респондентів. Отже, доцільно рекомендувати торговельним мережам найбільш активно використовувати SMS-розсилання споживачам, які внесені до баз даних (а також повідомлень через "WhatsApp", "Viber", оскільки вони можуть бути доповнені зображеннями, технологічно поширюються простіше, ніж, наприклад, MMS; проте, додатками поки що користуються значно менше рес- 
Пошук інформації через пошукові системи

Перегляд соціальних мереж

Перегляд відео онлайн

Обмін файлами, завантаження музики й фільмів

Електронне листування

IP-телефонія

可

Перегляд даних про товари й послуги на сайтах підприємств

Прослуховування музики онлайн

Читання онлайн інформаційних ресурсів

Обмін текстовими повідомленнями (ICQ, Yahoo та ін.)

Перегляд програм телебачення

Онлайн-ігри

Відвідування інформаційно-споживчих порталів

Участь у форумах

Ведення блогів

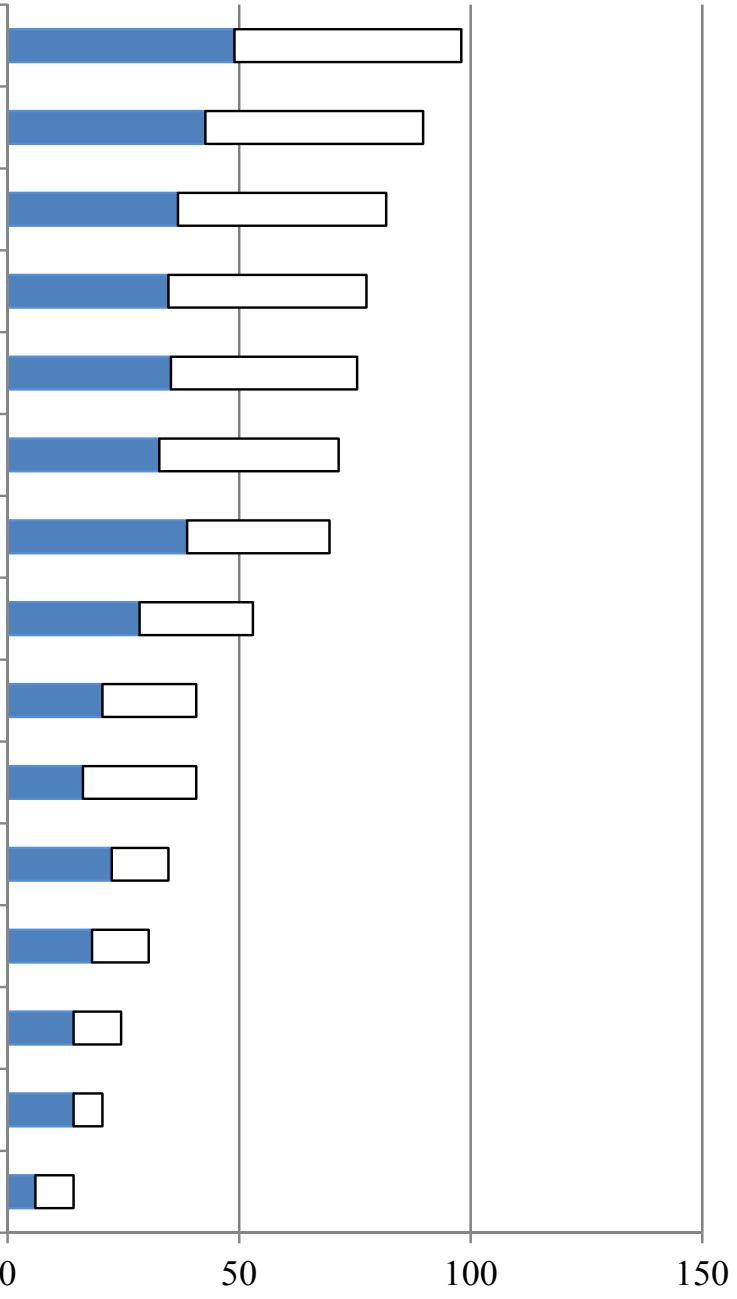

Чоловіки 口Жінки

Кількість, \%

Рис. 1. Рейтинг видів діяльності в мережі Інтернет користувачів персональних комп'ютерів (частки респондентів, \%)

Джерело: складено авторами за результатами власного дослідження

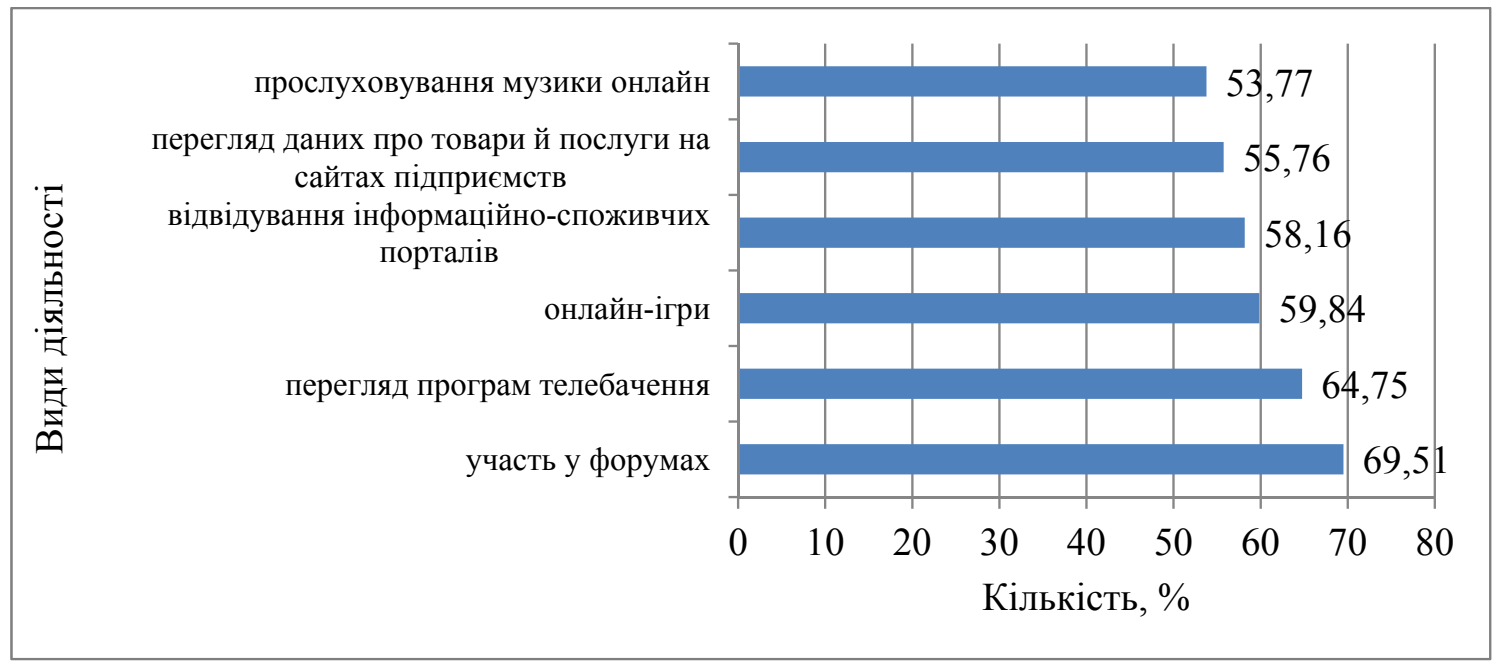

Рис. 2. Види діяльності в мережі Інтернет чоловіків-користувачів ПК, \% 


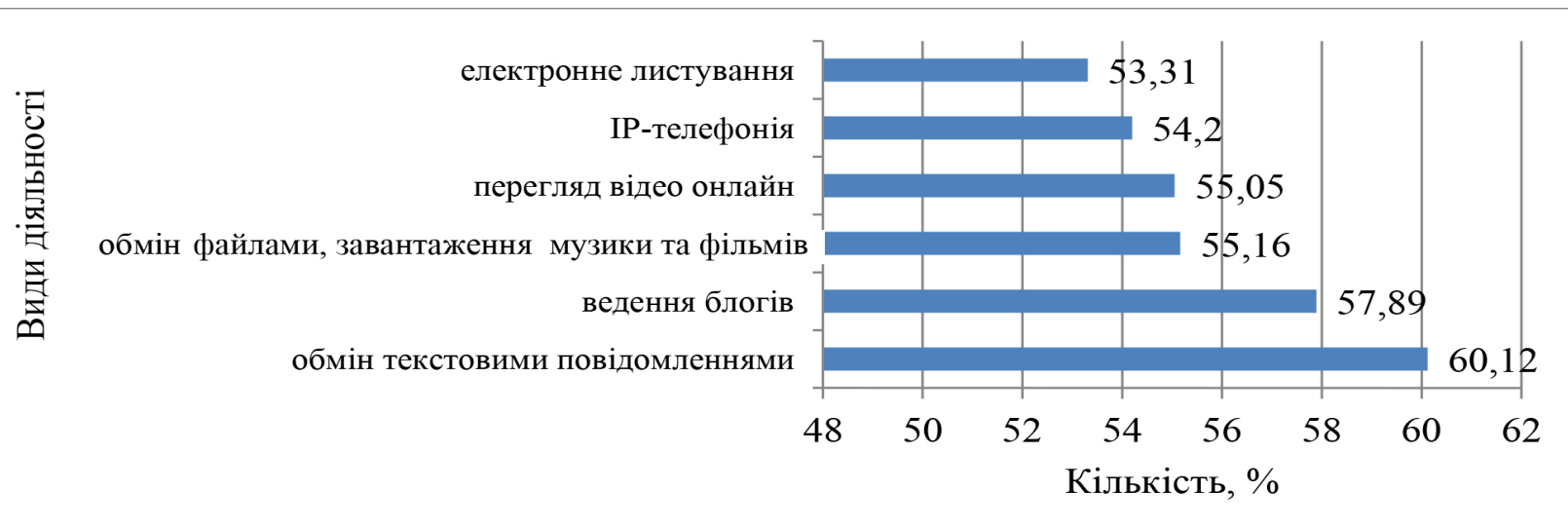

Рис. 3. Види діяльності в мережі Інтернет жінок-користувачів ПК, \%

Джерело: складено авторами за результатами власного дослідження

Таблиця 3

Частки вікових груп респондентів серед користувачів Інтернету через мобільні пристрої, \%

\begin{tabular}{|c|c|c|c|c|c|}
\hline \multirow{2}{*}{ Можливості Інтернету } & \multicolumn{5}{|c|}{ Вікові групи, років } \\
\hline & 19 і менше & $20-29$ & $30-39$ & $40-49$ & $50-55$ \\
\hline Голосовий зв'язок через мобільних операторів & & & 22,25 & & \\
\hline Відправлення/отримання SMS & & & 25,77 & & \\
\hline Фото- і відеокамери & & 26,02 & 26,02 & & \\
\hline Використання мобільних додатків & & 26,93 & & & \\
\hline Перегляд соціальних мереж & & 35,19 & & & \\
\hline Пошук інорормації через пошукові системи & 29,63 & & & & \\
\hline Перегляд відео & & & 30,04 & & \\
\hline Відправлення/отримання MMS & & & 28,38 & & \\
\hline mр3-плеєр & & 32,86 & & & \\
\hline IP-телесронія & & 29,53 & & & \\
\hline Текстові мессенджери & & 29,53 & & & \\
\hline Завантаження нових додатків & & 38,01 & & & \\
\hline Електронна пошта & & 28,65 & & & \\
\hline Відеозв'язок & & 34,15 & & & \\
\hline $\begin{array}{l}\text { Bluetooth (безпровідний короткохвильовий } \\
\text { зв'язок) }\end{array}$ & & 36,31 & & & \\
\hline GPS (глобальна система позиціонування) & & 37,21 & & & \\
\hline Перегляд телебачення & & & 32,56 & & \\
\hline Приватні повідомлення в соціальних мережах & 46,51 & & & & \\
\hline
\end{tabular}

Примітки: відсотки зазначені для тієї вікової категорії, частка якої серед користувачів є найбільшою

Інтенсивність використання можливості: $\quad$ - висока; $\quad$ - середня; $\square$ - низька.

Джерело: складено авторами за результатами власного дослідження

пондентів, ніж стандартним мобільним зв'язком). Актуальним питанням $€$ створення фрірмових мобільних додатків торговельних мереж, які дають змогу підтримувати постійний зв'язок 3 брендом. Як і в середовищі Інтернету, залишаються доцільними вірусні відео, реклама у соціальних мережах, контекстна реклама у пошукових системах, SEO-оптимізація офріційних сайтів; особливо слід наголосити на необхідності підтримувати мобільні версії сайтів, які б однаково вдало відображалися на всіх мобільних пристроях. Створення на сайтах особистих кабінетів споживачів, де міститься вся контактна інформація, дає змогу реалізувати концепцію омніканального маркетингу, тобто розпізнавати споживача й пропонувати йому одні й ті самі програми лояльності, $з$ якого би пристрою він не звернувся до місць продажу мережі.

Розподіл даних за статтю респондентів показав, що чоловіки більш активні в таких видах діяльності, як використання GPS, тобто глобальної системи позиціонування (чоловіки становлять 78,29\% серед усіх, хто надав відповідь); перегляд відео (66,67\%); електронна пошта (61,99\%); пере- 


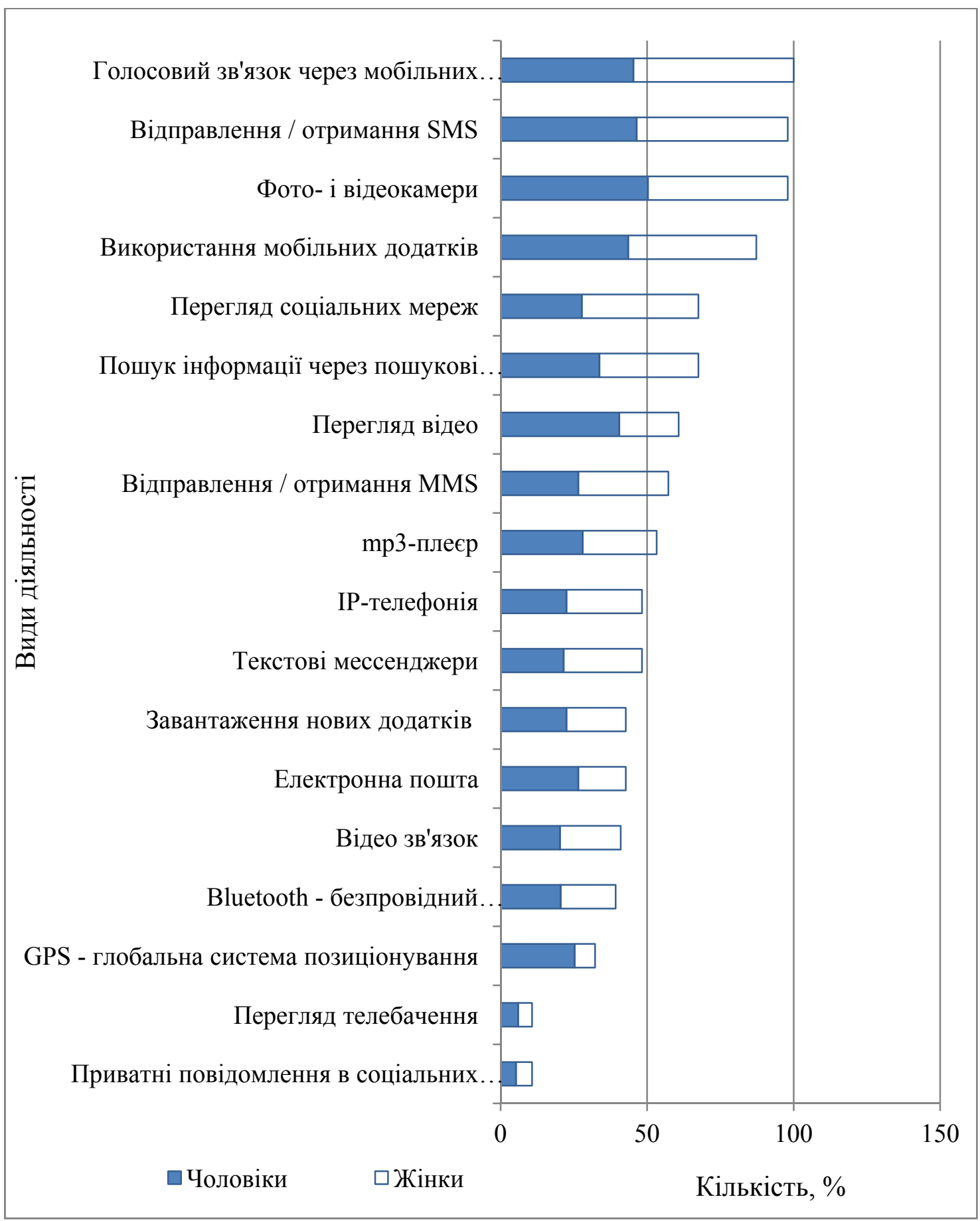

Рис. 4. Рейтинг видів діяльності користувачів мобільних пристроїв (частка респондентів, \%)

Джерело: складено авторами за результатами власного дослідження

гляд телебачення (55,81\%); завантаження нових додатків (52,63\%); прослуховування музики через тр3-плеєр (52,58\%) (рис. 5).

Жінки більш активні у перегляді соціальних мереж (58,89\%), використанні текстових месенджерів (55,44\%), відправленні/отриманні MMS (53,71\%), IP-телефонії (53,37\%) та відправленні/отриманні SMS (52,55\%) (рис. 6). Чоловіки у використанні мобільного зв'язку також віддають перевагу технічним аспектам (GPS, завантаження нових додатків) та розвагам, а жінки - спілкуванню; ці закономірності потрібно враховувати під час орієнтування комунікацій на чоловічу або жіночу аудиторію.

Висновки 3 проведеного дослідження. Серед основних тенденцій рекламно-інформаційного ринку прогнозується зміна моделі споживання інфрормації та послуг користувачами. Найбільш популярними є види віртуальної активності, пов'язаної з покупками товарів і послуг, а саме пошук та аналіз інформації, будь то 


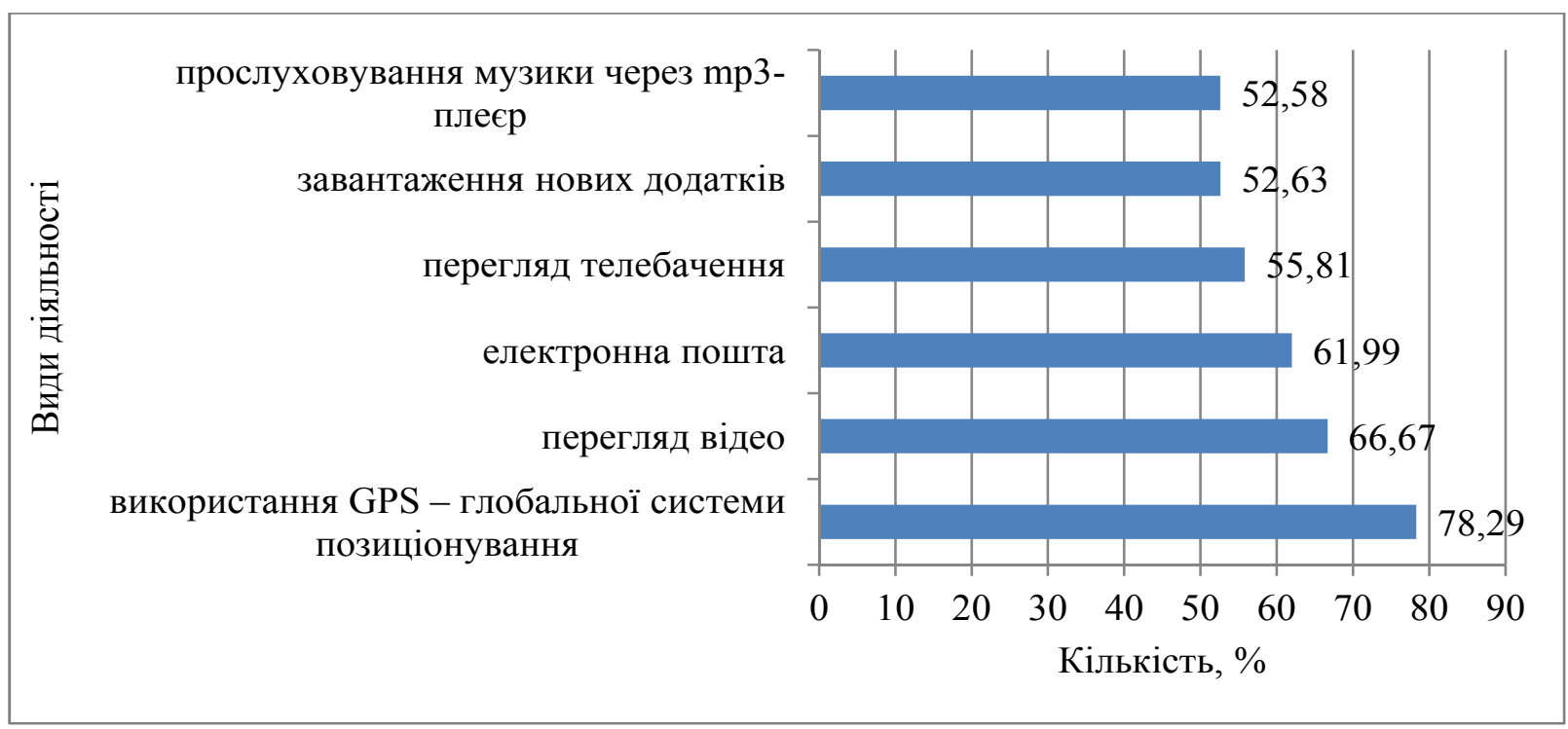

Рис. 5. Рейтинг видів діяльності чоловіків-користувачів мобільних пристроїв (частка респондентів, \%)

Джерело: складено авторами за результатами власного дослідження

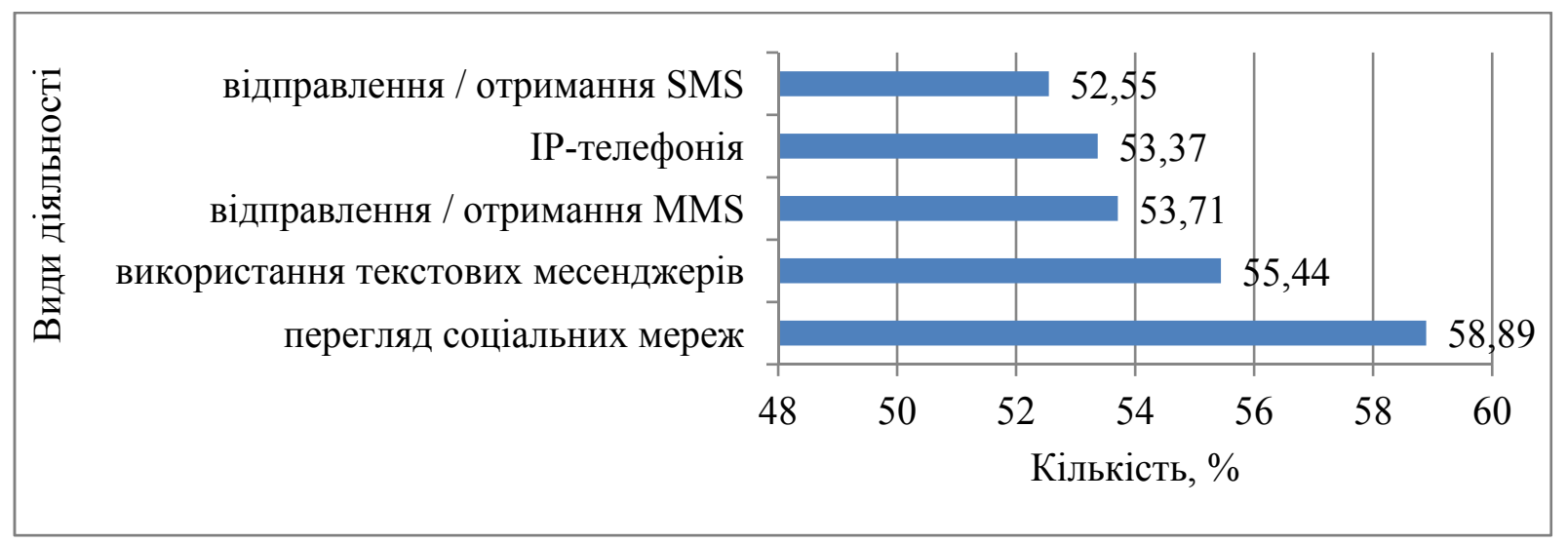

Рис. 6. Рейтинг видів діяльності жінок-користувачів мобільних пристроїв (частка респондентів, \%)

Джерело: складено авторами за результатами власного дослідження

читання відгуків інших споживачів, пошук товарів в Інтернеті, використання сервісів, пов'язаних з визначенням місця розташування, або порівняння цін у звичайних магазинах. Лідерство вдасться зберегти підприємствам, які активно підтримують інноваційну політику просування. Вікова аудиторія Інтернету та мобільного зв'язку максимально збігається $з$ аудиторією найбільш активних покупців побутових електротоварів, інсрормаційного та комунікаційного обладнання (це вікові групи 20-29 та 30-39 років). Оскільки саме інструменти digital-комунікацій дають змогу забезпечити індивідуальну адаптацію маркетингових пропозицій до вимог і потреб кожного покупця, саме ця група інструментів має бути пріоритетною в діяльності торговельних мереж 3 продажу побутової техніки, електроніки та засобів зв'язку.

\section{БІБЛІОГРАФІЧНИЙ СПИСОК:}

1. Скригун Н.П., Семененко К.Ю., Капінус Л.В. Види Інтернет-користувачів та їх характеристики в контексті забезпечення еорективних маркетингових комунікацій. Трансформаційні перетворення регіональної економіки : монографрія / за ред. С.А. Назаренка. Київ : Кондор, 2016. C. 8-22.

2.ОкороковС.С.Омниканальность:панацеяоткризиса или модный тренд. URL: http://roem.ru/01-06-2016/ 225473/omnikalnost (дата звернення: 6.08.2020).

3. Марченко В.Н., Лужнова Н.В. Трансформация коммуникативного инструментария маркетинговой деятельности розничных торговых сетей. Вестник ОГУ. 2014. № 14 (175). С. 200-206.

4. Радкевич Л.А., Луговська І.А., Кужилєва О.В., Матвієнко М.М. Стратегія розвитку Інтернетторгівлі торгової мережі на ринку ІТ-техніки : монограсрія / ред. О.М. Азарян. Донецьк : ДонНУЕТ, 2010. $248 \mathrm{C}$. 
5. Лабурцева О.І. Комунікаційні бренд-стратегії торговельних мереж України. Товари і ринки. 2019. Вип. 31. С. 5-18.

6. Всеукраїнська рекламна коаліція : офріційний сайт. URL: http://www.vrk.org.ua (дата звернення: 6.08.2020).

\section{REFERENCES:}

1. Skryhun N.P., Semenenko K.Yu. and Kapinus L.V. (2016), Vydy Internet-korystuvachiv ta ikh kharakterystyky $v$ konteksti zabezpechennia efektyvnykh marketynhovykh komunikatsij. Transformatsijni peretvorennia rehional'noi ekonomiky [Types of Internet users and their characteristics in the context of providing effective marketing communications. Transformational transformations of the regional economy], Kondor, Kyiv, Ukraine.

2. Okorokov S.S. Omnykanal'nost': panatseia ot kryzysa yly modnyj trend (2016). Available at: http://roem.ru/ 01-06-2016/225473/omnikalnost (accessed 6 August 2020).

3. Marchenko V.N. and Luzhnova N.V. (2014). Transformatsyia kommunykatyvnoho ynstrumentaryia marketynhovoj deiatel'nosty roznychnykh torhovykh setej [Transformation of the communication tools of the marketing activities of retail trade networks]. Vestnyk $\mathrm{OHU}$, Odessa, Ukraine.

4. Radkevych L.A., Luhovs'ka I.A., Kuzhylieva O.V. and Matviienko, M.M. (2010). Stratehiia rozvytku Internet-torhivli torhovoi merezhi na rynku IT-tekhniky [Strategy for the development of e-commerce trading network in the IT market]. DonNUET, Donets'k, Ukraine.

5. Laburtseva O.I. (2019). Komunikatsijni brendstratehii torhovel'nykh merezh Ukrainy [Communication brand strategies of trade networks of Ukraine]. Tovary $i$ rynky, Kyiv, Ukraine.

6. All-Ukrainian Advertising Coalition: Official site, available at: http://www.vrk.org.ua (Accessed 6 August 2020). 